\title{
Economic Freedom and Prosperity
}

Faculty Research Day, 2019

Congsheng Wu

Professor of International Finance

University of Bridgeport, Bridgeport, CT

\section{Introduction}

Adam Smith's well-known book, $A n$ Inquiry into the Nature and Causes of the Wealth of Nations, shows that free markets, the protection of private property rights and a minimal government interference in the economy lead to prosperity. The development economics literature has expansive evidence that economic freedom and sound legal, financial and political institutions boost economic growth. The basic ideas of Adam Smith has let economists to take an interest in economic and political institutions. Recent empirical work has analyzed country-level data on the gross domestic product (GDP). Another line of empirical research focuses on the link between economic freedom and economic growth.

This study investigates the association between the economic freedom, economic growth, and prosperity.

\section{Data}

Since 1995 the Wall Street Journal and the Heritage Foundation have tracked the march of economic freedom around the world with their influential Index of Economic Freedom. The index creates ten benchmarks that gauge the economic freedom of each country. The highest possible score is 100 , indicating perfect freedom. The Heritage Foundation describes economic freedom as the absence of government coercion or constraint on the production, distribution, or consumption of goods and services beyond the extent necessary for citizens to protect and maintain liberty itself. The table below provide the summary statistics of the main variables used in the study. The sample covers 176 countries over the years 2013 and 2019.

Table 1 Variables and Summary Statistics

\begin{tabular}{|c|c|c|c|}
\hline Variable & Min & Max & Mean \\
\hline Economic freedom score & 1.00 & 90.20 & 60.56 \\
\hline Property rights & 5.00 & 98.40 & 47.27 \\
\hline Government Integrity & 0.00 & 96.70 & 42.29 \\
\hline Government spending & 0.00 & 96.80 & 62.67 \\
\hline Tariff rate & 0.00 & 50.00 & 5.88 \\
\hline Corporate tax & 0.00 & 100.00 & 24.24 \\
\hline GDP (PPP, \$ million) & 0.19 & 23159.10 & 580.47 \\
\hline GDP Growth & -36.05 & 26.40 & 3.23 \\
\hline Five-year GDP growth & -7.80 & & \\
\hline GDP per capita & 348.10 & 143426.98 & 17805.5 \\
\hline
\end{tabular}

\section{Economic Freedom and Economic Growth}

The correlation coefficient between economic freedom and GDP growth is negative.

Regressing annual GDP growth rate on the economic freedom index yields the following results:

GDP growth $=4.42-0.02 *$ Economic freedom

The t-static is -1.25 , indicating that it is not significant statistically.

\section{Economic Freedom and Prosperity}

Figure 1 illustrates the relationship between economic prosperity, which is measured as the logarithm of a nation's gross domestic product (GDP) per capita, and economic freedom for 176 countries. A country's GDP is converted to the U.S. dollars using the purchasing power parity (PPP) implied exchange rates.

Figure 1 Prosperity and Economic Freedom

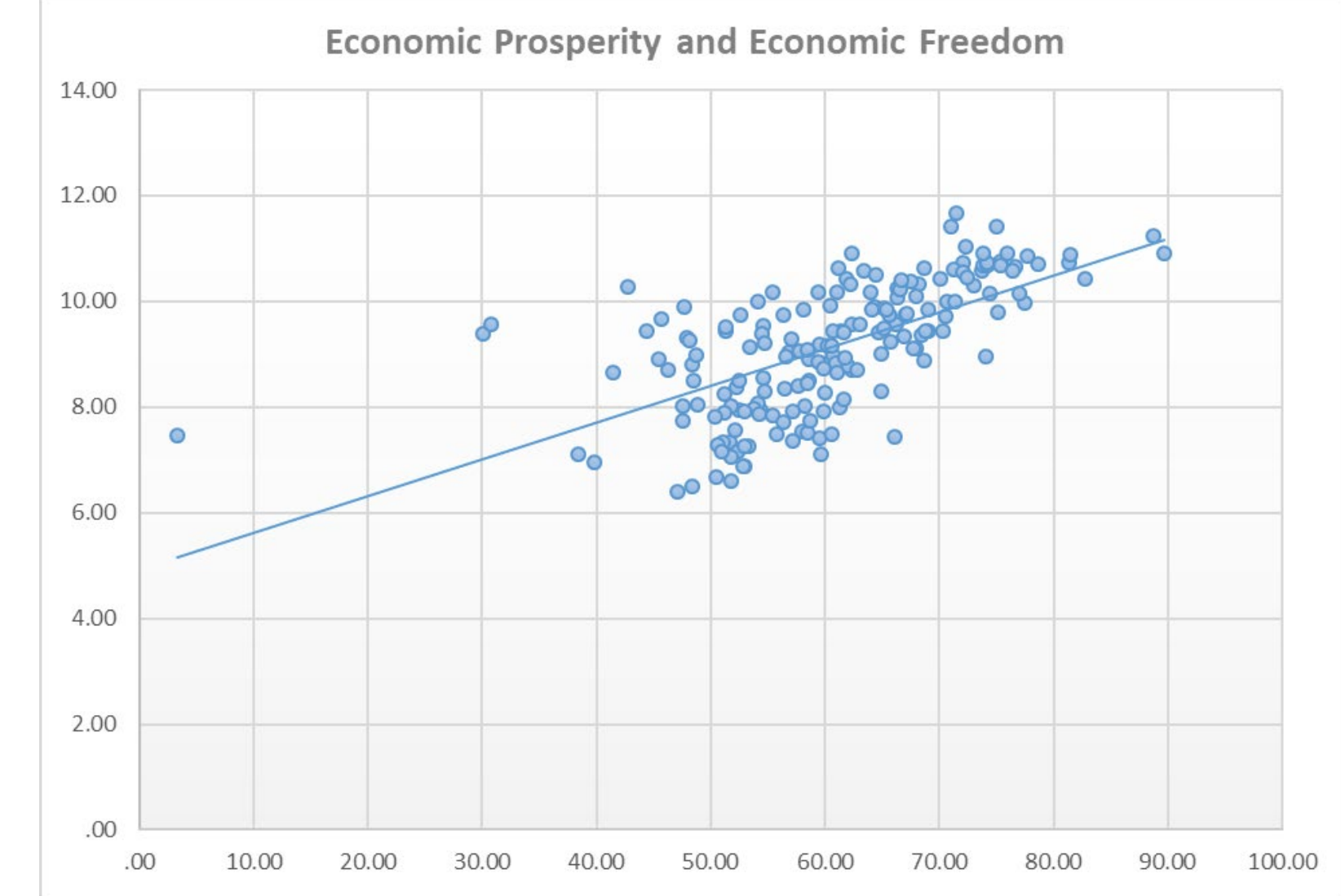

The figure shows a strong and positive association between economic freedom and GDP per capita.

\section{Regression Analysis}

In this section, I regress economic prosperity on economic freedom while controlling for other macroeconomic variables. The results are presented in Table 2. In the first regression, the only independent variable is economic freedom. The results shows that its coefficient estimate is positive and is significant at $1 \%$. In regression (2), two more variablesproperty rights and government integrity (i.e., free from corruption) - are added. All three independent variables have strong and positive coefficient estimates, implying that economic prosperity is strongly and positively associated with economic freedom, property rights protection, and government integrity.

\section{Regression Analysis, cont'd}

In the last regression, four more variables are added as independent variables. The results for economic freedom, property rights and government integrity remain basically unchanged. However, GDP per capita is negatively associated with government spending.

Similarly, economic prosperity is negatively associated with tariff rate. This result makes sense since high tariff rates are often imposed by developing countries. Corporate tax rate is also negatively linked to GDP per capita. Finally, contrary to common sense, fiveyear GDP growth rate is negatively related to economic prosperity.

\section{Table 2 Regression Analysis}

The dependent variable is the logarithm of GDP per indicate significance level at $1 \%, 5 \%$, and $10 \%$, respectively.

\begin{tabular}{|c|c|c|c|}
\hline $\begin{array}{c}\text { Independent } \\
\text { variable }\end{array}$ & $(1)$ & $(2)$ & $(3)$ \\
\hline Constant & $\begin{array}{c}4.69 \\
{[29.70]^{* * *}}\end{array}$ & $\begin{array}{c}6.71 \\
{[36.69]^{* * *}}\end{array}$ & $\begin{array}{c}8.58 \\
{[34.71]^{* * *}}\end{array}$ \\
\hline $\begin{array}{c}\text { Economic } \\
\text { freedom }\end{array}$ & 0.073 & 0.013 & 0.010 \\
\hline$[28.76]^{* * *}$ & {$[3.09]^{* *}$} & {$[1.79]^{*}$} \\
\hline Property rights & & 0.021 & 0.018 \\
& & {$[8.59]^{* * *}$} & {$[7.59]^{* * *}$} \\
\hline $\begin{array}{c}\text { Government } \\
\text { integrity }\end{array}$ & & 0.015 & 0.010 \\
\hline Government & & {$[5.72]^{* * *}$} & {$[3.65]^{* * *}$} \\
\hline spending & & & -0.005 \\
\hline Tariff rate & & & {$[-4.00]^{* * *}$} \\
\hline Corporate tax & & & -0.032 \\
& & & {$[-5.40]^{* * *}$} \\
\hline Five-year growth & & & -0.025 \\
\hline Adj R & & & $-9.53]^{* * *}$ \\
\hline F-value & 0.403 & 0.041 \\
\hline & 829.11 & 447.29 & {$[-4.49]^{* * *}$} \\
\hline & & & 0.60 \\
\hline
\end{tabular}

\section{Conclusions}

1. Economic freedom does not determine economic growth. In fact, there is a negative correlation between annual GDP growth and economic freedom. This result can be partly explained by the fact that strong economic growth often take place in developing countries, which in general score low in economic freedom.

2. However, the association between economic prosperity, as measured by GDP per capita, and economic freedom is strong and positive.

3. The causal relationship between prosperity and economic freedom is not clear. Further study is needed . 